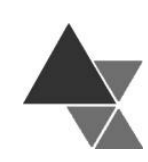

\title{
Fatores antinutricionais na alimentação humana
}

\author{
Neide Setsuco Higashijima ${ }^{1}$, Alessandra Lucca ${ }^{2}$, Luana Rurico Higashijima Rebizzi ${ }^{3}$ e \\ Leila Mary Higashijima Rebizzi ${ }^{4}$
}

Fatores antinutricionais são compostos oriundos do metabolismo secundário das plantas, presentes numa extensa variedade de alimentos de origem vegetal. Este trabalho teve como objetivo pesquisar os diversos fatores antinutricionais, em especial o ácido cianídrico, o ácido fítico e o ácido oxálico, presentes nos alimentos do nosso dia a dia, as consequências quando há alta ingestão dos mesmos e os métodos de redução desses antinutrientes no preparo dos alimentos como remolho, germinação, cozimento, fatiagem, maceração, trituração, ralagem, fermentação, maltagem, moagem, secagem e torrefação. A metodologia utilizada foi revisão de literatura. A partir desta revisão, conclui-se que tanto o ácido cianídrico como o ácido fítico pode ser reduzido nos alimentos por meio de processos utilizados tanto na preparação doméstica como na industrial, e que a melhor forma de redução do ácido oxálico insolúvel é evitando ou minimizando o consumo de alimentos que o contém.

Palavras chave: Fatores antinutricionais, leguminosas, ácido fítico, fitato, ácido oxálico, oxalato, ácido cianídrico, mandioca, ruibarbo.

\section{Antinutritional factors in human food}

Antinutritional factors are compounds derived from the secondary plants' metabolism, present in an extensive variety of plant origin foods. The objective of this work was to investigate the different antinutritional factors, especially hydrocyanic acid, phytic acid and oxalic acid, present in our daily food, the consequences of high ingestion of this acids and the methods of reducing these antinutrients in the preparation of foods such as towing, germination, cooking, slicing, maceration, grinding, grating, fermentation, malting, milling, drying and roasting. The methodology used was literature review. From this review, it is concluded that both hydrocyanic acid and phytic acid can be reduced in food by processes used in both domestic and industrial preparation and that the best way of reducing insoluble oxalic acid is by avoiding or minimizing the consumption of food containing it.

Keywords: Antinutritional factors, legumes, phytic acid, phytate, oxalic acid, oxalate, hydrocyanic acid, cassava, rhubarb.

${ }^{1}$ Nutricionista pela Universidade Paulista e Pós-Graduada em Nutrição e Fitoterapia pelo Ganep/Feluma. Endereço para correspondência: Rua Apeninos no 267 - Aclimação - São Paulo - SP - Brasil. CEP: 01533-000. Tel.: (11) 997527723. E-mail: neideset@yahoo.com.br

2 Professora Doutora e docente titular da Universidade Paulista

3 Farmacêutica Bioquímica e pós-graduada pela Universidade de São Paulo

4 Educadora Física e pós-graduada pela Universidade de São Paulo 


\section{INTRODUÇÃO}

Os alimentos de origem vegetal, além de apresentarem substâncias nutritivas essenciais para a saúde, podem também conter fatores antinutricionais, como o ácido cianídrico, ácido fítico, ácido oxálico, proteínas inibidoras de protease, taninos, nitritos, nitratos, entre outros. São assim denominados, por interferirem na absorção de nutrientes ou serem tóxicos, podendo acarretar danos à saúde quando ingeridos em grande quantidade[1].

Fatores antinutricionais (FANs) são compostos oriundos do metabolismo secundário das plantas, presentes numa extensa variedade de alimentos de origem vegetal, que quando consumidos, reduzem o valor nutritivo desses alimentos, pois interferem na digestibilidade, absorção ou utilização de nutrientes $[1,2,3]$, e se ingeridos em grandes quantidades podem provocar efeitos fisiológicos adversos como reações tóxicas ou diminuir a biodisponibilidade de nutrientes ${ }^{[4]}$ como minerais e aminoácidos essenciais, além de poder causar irritações e lesões na mucosa gastrintestinal, interferindo assim na seletividade e eficiência dos processos biológicos ${ }^{[1]}$.

Esses compostos, FANs, quando consumidos em grande quantidade podem ser tóxicos e em casos extremos, letais. Em pequenas concentrações podem ser benéficos para a saúde como antioxidantes, protetores do sistema circulatório, redutores da pressão sanguínea, reguladores da glicemia e da colesterolemia, anticancerígenos, antimicrobianos, melhoradores da resposta imune, etc., e, portanto, são denominados "fatores nutricionalmente ativos" ou "compostos bioativos" por apresentarem também efeitos benéficos e eles são valorizados por seu uso farmacêutico ${ }^{[4,5]}$.

Alguns FANs são termolábeis, desaparecendo após cozimento adequado, outros são termoestáveis, podendo dissipar-se por dissolução em água[ ${ }^{[4]}$.

No caso das leguminosas, os FANs são sintetizados e acumulados durante a maturação da semente, para o processo germinativo ou como mecanismo de defesa da planta, pois atuam contra bactérias, vírus, fungos, insetos e animais. A concentração desses compostos difere dependendo da época da colheita, etapa de desenvolvimento da planta, tipo de solo e sua adubação[5].
Um único alimento pode apresentar diversos FANs, como por exemplo, a semente de quinoa, onde os FANs identificados foram: saponinas, ácido fítico, taninos, nitratos, oxalatos e inibidores de tripsina. Essas substâncias encontram-se presentes em maior concentração nas camadas externas do grão[3]. As sementes das leguminosas contêm inibidores de tripsina, fitatos, polifenóis (principalmente taninos nos feijões) e oligossacarídeos (rafinose e estaquiose) ${ }^{[4]}$.

No fruto da lichia, os FANs encontrados foram nitrato e inibidores de tripsina, de $\alpha$-amilase e de lipase pancreática. $\mathrm{Na}$ lichia (Litchi cbinensis Sonn) do cultivar Bengal de Nepomuceno (MG), foram avaliados os fatores antinutricionais citados acima, sendo que os teores de nitrato encontrados variaram de 51,98 a $351,81 \mathrm{mg} / 100 \mathrm{~g}$ (polpa fresca, semente fresca e seca, casca fresca e seca), sendo o teor de $51,98 \mathrm{mg} / 100 \mathrm{~g}$ referente à polpa fresca, e portanto viável para o consumo humano[].

Durante o processamento de alimentos, diferentes metodologias modernas (extrusão/cocção, micro-ondas, altas pressões, aquecimento por infravermelho (micronização) e campos elétricos) e tradicionais (descasque, cocção, torrefação, remolho, germinação e fermentação) são aplicados para reduzir ou eliminar os FANs ${ }^{[5]}$.

O remolho consiste na hidratação das sementes, até alcançar seu peso máximo. É um método de redução de alguns componentes solúveis em água como ácido fítico, oligossacarídeos, saponinas, inibidores de protease, oxalato solúvel e taninos, que passam para a água de remolho. O grau de eliminação de FANs depende da temperatura de remolho, do pH do meio, do tipo de leguminosa e das propriedades de solubilidade dos componentes. Em sementes de feijão-caupi, ervilha e feijão, o remolho durante 18 a 22 horas reduziu taninos (50-90\%), oligossacarídeos (44\%), ácido fítico (42-48\%) e inibidores de tripsina (10-19\%). O remolho em água de sementes de lentilha durante 9 horas em temperatura ambiente reduziu em $11 \%$ o ácido fítico $\left[{ }^{[}\right.$.

A germinação é a prática de imersão de sementes em água até germinar e começar a brotar. Esta prática é relatada como associada a melhorias no valor nutritivo das sementes. Ao mesmo tempo, existem indícios de que a germinação é efetiva na redução do ácido fítico e oligossacarídeos (estaquiose e 
rafinose responsáveis pela flatulência), aumentando assim a digestibilidade das proteínas e melhorando as propriedades sensoriais. No caso de feijão branco, fava e grão-de-bico, a germinação melhorou a digestibilidade das proteínas, diminuindo os fatores antinutricionais $[7,8]$.

A fermentação de alimentos é um método microbiano e enzimático para o processamento de alimentos, para obter uma vida útil prolongada $\mathrm{e}$ redução de FANs. A fermentação láctica é o método preferido para a fermentação de cereais e leguminosas como milho, soja e sorgo[?].

Em geral, a cocção produz a desnaturação das proteínas e sua difusão na fase líquida, inativa os
FANs sensíveis ao calor [5]. De acordo com os resultados obtidos, a cocção pode ser um método recomendável para a redução de FANs em vegetais, visto que em estudos realizados com taninos e ácido fítico ocorreram reduções médias de 30\% após 10 minutos de cozimento doméstico[2].

Os fatores que reduzem a biodisponibilidade de cálcio são o ácido oxálico e o ácido fítico[3,10,11,12].

O Quadro 1 sumariza os principais fatores antinutricionais, os alimentos que os contém e seus efeitos.

Quadro 1. Fatores antinutricionais, alimentos que os contém e seus efeitos

\begin{tabular}{|c|c|c|}
\hline Fatores antinutricionais & Alimentos & Efeitos \\
\hline Ácido cianídrico & $\begin{array}{l}\text { Mandioca }{ }^{[1,13,14,15]} \text { folha da mandioca }{ }^{[1,16]} \text {; } \\
\text { tremoço }{ }^{[5]} \text {; sorgo, linho, trevo branco, bambu, } \\
\text { seringueira, sementes de ameixa e damasco }{ }^{[14,15]} \text {; } \\
\text { linhaça, grãos jovens de sorgo e sementes de pera, } \\
\text { maçã, pêssego e cereja }{ }^{[1]} \text {. }\end{array}$ & $\begin{array}{l}\text { É uma substância tóxica, e estima-se que o consumo } \\
\text { de alimento contendo uma concentração entre } 0,5 \text { a } \\
3,5 \mathrm{mg} \text { de HCN por kg de peso corpóreo, possa levar o } \\
\text { indivíduo à morte em poucos minutos }{ }^{[1]} \text {. }\end{array}$ \\
\hline Ácido fítico & $\begin{array}{l}\text { Feijão[3,9,10,11,12,17,18]; lentilha e ervilha }{ }^{[3,9,10,11,12,19]} \text {; } \\
\text { proteína texturizada de soja, sementes, nozes e } \\
\text { cereais integrais }{ }^{[3,10,11,12]} \text {; quinoa, centeio e trigo }{ }^{[3,7,20]} \text {; } \\
\text { farelo integral de arroz }{ }^{19]} \text {; milho, farelo de aveia, } \\
\text { arroz, sorgo, grão-de-bico, soja, sementes de } \\
\text { gergelim, grão de amaranto, trigo sarraceno e } \\
\text { amendoim }{ }^{[9,18]} \text {. }\end{array}$ & $\begin{array}{l}\text { São quelantes de minerais como cálcio, ferro, } \\
\text { magnésio, zinco, cobre e potássio, comprometendo a } \\
\text { biodisponibilidade desses nutrientes }{ }^{[3,9,21]} \text {. }\end{array}$ \\
\hline Ácido oxálico & $\begin{array}{l}\text { Espinafre, ruibarbo, beterraba e acelga }{ }^{[1,3,10,11,12,22,23]} \text {; } \\
\text { carambola, folha de beterraba, nozes, cacau, feijão, } \\
\text { batata doce e tomate }{ }^{[1,3,10.11 .12]} \text {; broto de bambu }{ }^{[22,23]} \text {; } \\
\text { oleaginosas, chá preto, amendoim, soja, } \\
\text { concentrados de farelo e cereais }{ }^{[23]} \text {; amêndoas, } \\
\text { avelãs e pistache }{ }^{[24,25]} \text {; trigo-mourisco, azedinha, } \\
\text { amaranto e quinoa }{ }^{[3]} \text {. }\end{array}$ & $\begin{array}{l}\text { Substânciatóxica, sendo a dose letal } 1.500 \mathrm{mg}^{[26]} \text {. } \\
\text { Influencia na absorção de minerais como cálcio, } \\
\text { magnésio, sódio, potássio, e desempenha papel-chave } \\
\text { na hiperoxalúria, com formação de cálculos de oxalato } \\
\text { de cálcio nos rins }{ }^{[3]} \text {. }\end{array}$ \\
\hline Inibidores de protease & $\begin{array}{l}\text { Ervilha, feijão, amendoim, arroz, soja, milho, batata, } \\
\text { e feijão guandu }{ }^{27]} \text {. }\end{array}$ & $\begin{array}{l}\text { Inibem as enzimas que digerem proteínas. São capazes } \\
\text { de inibir as atividades da tripsina, quimotripsina e } \\
\text { carboxipeptidase }{ }^{[2]} \text {. }\end{array}$ \\
\hline Nitrato/Nitrito & $\begin{array}{l}\text { Quinoa e repolho }{ }^{[3]} \text {; folhas de brócolis, couve e } \\
\text { couve-flor }{ }^{[2]} \text {; lichia }{ }^{[6]} \text {; espinafre, alface, rabanete e } \\
\text { beterraba[28]; produtos cárneos, peixes e aves } \\
\text { processados e defumados }{ }^{[26]} \text {. }\end{array}$ & $\begin{array}{l}\text { Interfere no metabolismo da vitamina } \mathrm{A} \text { e nas funções } \\
\text { da glândula tireóide }{ }^{[1]} \text { Tem elevado potencial } \\
\text { carcinogênico, teratogênico e mutagênico }{ }^{[26]} \text {. O } \\
\text { consumo excessivo de nitrato pode causar cianose } \\
\text { decorrente da formação de metamioglobina e neoplasia } \\
\text { a partir da formação de compostos N-nitrosos }{ }^{\left[{ }^{6}\right]} \text {. }\end{array}$ \\
\hline Saponinas & $\begin{array}{l}\text { Aveia, quinoa, pimentas, berinjela, semente de } \\
\text { tomate, aspargos, inhame, feno-grego e ginseng }{ }^{[3]} \text {. }\end{array}$ & $\begin{array}{l}\text { Podem formar complexos com ferro e zinco, } \\
\text { reduzindo a sua absorçãoo }{ }^{[3]} \text {. Influenciam na absorção } \\
\text { de carboidratos, lipídios e proteínas e inibem a } \\
\text { atividade de enzimas digestivas }{ }^{[29]} \text {. }\end{array}$ \\
\hline Taninos & $\begin{array}{l}\text { Vinhos tintos, chás, frutas verdes, feijão, uva, maçã, } \\
\text { cacau, chocolate e quinoa }{ }^{[3]} \text {; caqui, banana, ervilha e } \\
\text { amaranto }^{[1]}\end{array}$ & $\begin{array}{l}\text { Podem reduzir a digestibilidade das proteínas e } \\
\text { carboidratos, diminuir a atividade de enzimas } \\
\text { digestivas, além de causar danos à mucosa do sistema } \\
\text { digestório ou exercer efeitos tóxicos sistêmicos }{ }^{[1]} \text {. } \\
\text { Limitam a biodisponibilidade dos minerais como o } \\
\text { ferro e zinco[5]. }\end{array}$ \\
\hline
\end{tabular}


Devido a esses FANs estarem contidos nos alimentos consumidos no dia a dia, e o impacto que pode causar sobre a saúde, se faz bastante importante o conhecimento dos alimentos que os contém, assim como as formas de redução desses fatores. Assim, o objetivo da presente revisão é descrever os diversos FANs presentes nos alimentos consumidos no nosso dia a dia, suas consequências quando ingeridos em grande quantidade e os métodos empregados para a redução dos mesmos.

\section{METODOLOGIA}

Trata-se de uma revisão de literatura, realizada por meio de levantamento bibliográfico, mediante consulta às bases de dados Scientific Electronic Library Online (SCIELO), Biblioteca Virtual em Saúde - BVS (LILACS), US National Library of Medicine National Institutes of Health (PubMed). Foram consultados artigos publicados no período de 2000 a 2017.

Para seleção foram utilizados os seguintes descritores: fatores antinutricionais, leguminosas, ácido fítico, fitato, ácido oxálico, oxalato, ácido cianídrico, mandioca, ruibarbo. A seleção de todos os artigos foi, numa fase inicial, efetuada por meio da leitura dos respectivos títulos e resumos (abstracts), recorrendo-se ainda à pesquisa das listagens de referências de estudos identificados. No total, 79 artigos foram encontrados e selecionados. Após triagem, 39 artigos e 1 livro reuniram os critérios considerados elegíveis para inclusão na análise: ter conteúdo especificamente relacionado ao tema fatores antinutricionais e sua ação no organismo, abordar os fatores antinutricionais a serem estudados (ácido cianídrico, ácido fítico e ácido oxálico), além de serem publicados em português, espanhol ou inglês. Após leitura e sumarização dos incluídos, a informação extraída foi reunida e compilada por meio de quadros, nas quais foram colocados os aspectos mais relevantes de cada um dos estudos.

\section{RESULTADOS}

\section{Ácido Cianídrico (HCN)}

Nas plantas o HCN se encontra ligado a carboidratos denominados glicosídeos cianogênicos, sendo liberado após a sua hidrólise. O HCN é detoxificado metabolicamente pela enzima rodanase, que o transforma em tiocianato, substância atóxica. Além da detoxificação metabólica, o HCN pode ser detoxificado por meio de aquecimento, trituração, prensagem onde os glicosídeos cianogênicos são arrastados com a água, fermentação e desidratação[15].

A capacidade de produzir ácido cianídrico é um fenômeno encontrado em aproximadamente 2.000 espécies de plantas. Os compostos cianogênicos podem funcionar como formas de transporte de nitrogênio reduzido ou de moléculas químicas na defesa contra herbívoros, insetos e moluscos. Muitas espécies vegetais como o sorgo, linho, ameixa, damasco, trevo branco, bambu, seringueira e mandioca, apresentam diferentes quantidades de

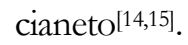

Algumas variedades de mandioca ou aipim ou macaxeira apresentam em sua composição, os glicosídeos cianogênicos linamarina e lotaustralina, que liberam o ácido cianídrico, composto extremamente tóxico, mas que é termolábil, assim pode ser inativado com o processamento térmico ${ }^{[14]}$.

A mandioca é a planta mais importante dentre as produtoras de cianeto. Em todos os seus tecidos, com exceção das sementes, há grande quantidade dos glicosídeos cianogênicos, ocorrendo diferenças consideráveis entre as variedades, sendo que nas folhas, ramos e casca da raiz tuberosa encontram-se níveis mais altos de glicosídeos cianogênicos do que na própria polpa da raiz. Essa concentração é maior nas folhas jovens do que nas adultas. O córtex de uma raiz de variedade mansa pode conter maior teor de cianeto do que na polpa de uma variedade brava. A quantidade de cianeto nessas raízes tuberosas difere de acordo com a variedade, podendo ser encontrados valores entre 22 e $1.000 \mathrm{mg} / \mathrm{kg}$ de polpa frescal ${ }^{[1,14]}$.

Dentre os glicosídeos cianogênicos encontrados naturalmente nos alimentos vegetais, temse a amigdalina, encontrada nas sementes de frutos da família das Rosáceas (pera, maçã, pêssego, cereja); a linamarina e lotaustralina, encontrados na mandioca e linhaça e a durrina, encontrada nos grãos jovens de sorgo. A concentração dos glicosídeos cianogênicos varia nas diferentes espécies de plantas, e numa mesma espécie também pode variar dependendo do clima e outras condições que influenciam o crescimento da planta como adubação nitrogenada, falta de água e idade da planta, pois quanto mais nova e de 
crescimento rápido, maior será o teor em glicosídeos cianogênicos ${ }^{[1,15]}$.

É importante ressaltar que a raiz tuberosa da mandioca com elevados teores de linamarina potencialmente hidrolisáveis a cianeto, pode apresentar elevado valor residual na elaboração da farinha de mandioca caso a destoxificação (degradação do $\mathrm{HCN}$ ) não seja eficaz durante o processamento. No decorrer da produção da farinha de mandioca do grupo seca, a raiz de mandioca fresca e descascada apresentou teor inicial de $160 \pm 11,8 \mathrm{mg} \mathrm{HCN} / \mathrm{kg}$, confirmando a caracterização da raiz tuberosa como brava ou venenosa, por possuir teor de cianeto superior a $100 \mathrm{mg} \mathrm{HCN} / \mathrm{kg}^{[13]}$.

Plantas cianogênicas, como a mandioca, apresentam compostos cianogênicos e enzimas distribuídas em concentrações variáveis nas suas diferentes partes. Pela ruptura da estrutura celular da raiz tuberosa, as enzimas presentes (linamarase, $\beta$ glicosidase) degradam estes compostos, liberando o $\mathrm{HCN}$, que é o princípio tóxico da mandioca e cuja ingestão ou mesmo inalação, representa sério perigo à saúde, podendo apresentar sintomas de intoxicação dependendo da quantidade e tipo de alimento ingerido, chegando ao envenenamento em casos extremos. Estima-se que o consumo de alimento contendo $\mathrm{HCN}$, em uma concentração entre 0,5 a 3,5mg de $\mathrm{HCN}$ por $\mathrm{kg}$ de peso corpóreo, possa levar $\mathrm{o}$ indivíduo à morte em poucos minutos. Entretanto, o risco de intoxicação pode ser minimizado a partir da utilização de processos de preparação como cozimento, fritura, trituração, secagem e torrefação, que reduzem o teor desse composto[1,16].

Em 2004, foidetectado na multimistura produzida em Pelotas (RS), $85 \mathrm{mg} / \mathrm{kg}$ de $\mathrm{HCN}$ no pó da folha de mandioca seca, sendo que foi encontrada em folha de mandioca fresca $800-1600 \mathrm{mg} / \mathrm{kg}$. A melhor forma de trabalhar a folha de mandioca, a fim de obter uma maior redução do teor de ácido cianídrico, é a técnica de amassar e rasgar as folhas antes de as colocar para secar. Isso faz com que a enzima linamarase (presente na própria folha, mas em compartimentos separados) entre em contato com os glicosídeos cianogênicos, linamarina e lotaustralina, decompondo-os a cianohidrinas até ácido cianídrico. Por se tratar de um gás, o ácido cianídrico presente na folha facilmente se dissipa no ar, ocorrendo assim uma expressiva saída dessa substância tóxica da folha da mandioca[1,16].

Várias leguminosas são tóxicas pelo seu conteúdo em glicosídeos cianogênicos, que por hidrólise liberam HCN. Este composto, presente nos feijões, está relacionado historicamente com casos de envenenamento, no entanto, as variedades atualmente consumidas (melhoramento genético) possuem conteúdo substancialmente inferior de $\mathrm{HCN}$. Quando o feijão é deixado de remolho e cozido em água, a hidrólise se produz rapidamente, liberando $\mathrm{HCN}$, que se perde volatilizado[4].

Quadro 2. Teor de ácido cianídrico $(\mathrm{mg} / \mathrm{kg})$ em mandioca

\begin{tabular}{|c|c|}
\hline Mandioca & $\begin{array}{l}\text { Ácido cinanídrico ( } \mathrm{mg} / \mathrm{kg}) \\
\text { Média e desvio padrão }\end{array}$ \\
\hline Raiz fresca e descascada (brava) & $160 \pm 11,8$ \\
\hline Raiz triturada & $149 \pm 12,3$ \\
\hline Raiz triturada e prensada & $68 \pm 2,5$ \\
\hline Farinha pronta & $5 \pm 0,2$ \\
\hline Raiz fresca para farinha d'água & $321 \pm 21,6$ \\
\hline 24 horas de fermentação (farinha d'agua) & $297 \pm 2,7$ \\
\hline 96 horas de fermentação (farinha d'agua) & $64 \pm 2,3$ \\
\hline Após prensagem da massa fermentada (24 horas) & $50 \pm 0,6$ \\
\hline Após prensagem da massa fermentada (96 horas) & $36 \pm 0,4$ \\
\hline Folha fresca* & $800-1600$ \\
\hline Folha seca em pó* & 85 \\
\hline
\end{tabular}




\section{Ácido Fítico $\left(\mathrm{C}_{6} \mathrm{H}_{18} \mathrm{O}_{24} \mathrm{P}_{6}\right)$}

Os fitatos são derivados do ácido fítico ou ácido hexafosfórico mioinositol, um ácido orgânico utilizado pelas plantas para armazenamento de fósforo durante a maturidade da semente[ ${ }^{[3]}$, pois o fitato se acumula nas sementes durante $\mathrm{o}$ período de amadurecimento[9], sendo que em sementes dormentes representa $60-90 \%$ do fosfato total[ ${ }^{[18]}$.

Os fitatos são componentes do pericarpo de grãos, que se encontram associados a proteínas e apresentam a propriedade de se ligarem a minerais ${ }^{[4]}$.

A estrutura única do ácido fítico oferece a capacidade de quelar fortemente cátions como cálcio, magnésio, zinco, cobre, ferro e potássio para formar sais insolúveis. O fitato funciona em uma ampla faixa de $\mathrm{pH}$ como um íon altamente carregado negativamente e, portanto, sua presença na dieta tem um impacto negativo sobre a biodisponibilidade de íons minerais divalentes e trivalentes, como o $\mathrm{Zn}^{2+}$, $\mathrm{Fe}^{2+}, \mathrm{Fe}^{3+}, \mathrm{Ca}^{2+}, \mathrm{Mg}^{2+}, \mathrm{Mn}^{2+}$ e $\mathrm{Cu}^{2+[9]}$. Portanto, o ácido fítico ao formar complexos resistentes à ação do trato intestinal, diminui a biodisponibilidade desses minerais ${ }^{[1,21]}$.

O ácido fítico é encontrado, principalmente, na casca da maioria dos cereais e leguminosas, em concentrações de 1 a 3\% de matéria seca[3]. Portanto, são encontrados nos feijões, lentilha, ervilha, proteína texturizada de soja, sementes, nozes e grãos integrais $[3,10,11,12]$.

$\mathrm{Na}$ alimentação humana, as dietas ricas em fibras de cereais, leguminosas e proteína de soja resultam numa alta ingestão de fitato. Este, por sua vez, tem um grande potencial para ligar-se de forma positiva a proteínas carregadas, aminoácidos, e/ou cátions multivalentes nos alimentos. Os complexos resultantes são insolúveis, difíceis para os seres humanos hidrolisarem durante a digestão, sendo assim são nutricionalmente menos disponíveis para absorção. Tem sido ainda demonstrado que o fitato pode afetar a digestibilidade do amido interagindo com a amilase ${ }^{[30]}$. No caso do feijão, o ácido fítico se liga ao amido através do fosfato, reduzindo assim a digestibilidade do amido[17].

Técnicas de processamento biológico como remolho, germinação, maltagem e fermentação, reduzem o conteúdo de fitato, aumentando a atividade da fitase naturalmente presente nas plantas e em microorganismos, resultando na desfosforilação do fitato. A suplementação de fitase nas dietas resulta em aumento na absorção de minerais. Também é indicado em cozimentos, a adição de fitases exógenas estáveis ao calor, pois deve permanecer ativa, mesmo a alta temperatura e em uma ampla faixa de $\mathrm{pH}{ }^{[0]}$.

Durante a estocagem, remolho, fermentação, germinação, processamento, cocção e digestão dos grãos e sementes, o fitato vai perdendo ligações fosfato transformando-se de um hexafosfato de inositol em pentafosfato (IP5), tetrafosfato (IP4), trifosfato (IP3) e possivelmente, inositol difosfato (IP2) e monofosfato (IP1), por ação de fitases endógenas do alimento. Somente o IP5 tem efeito negativo na biodisponibilidade de minerais, complexando o ferro e zinco, enquanto IP4 e IP3 não apresentam esta característica. Portanto, durante a cocção, o fitato vai perdendo ligações fosfato transformando-se de um hexafosfato de inositol, em penta, tetra ou trifosfato, perdendo, portanto, a sua capacidade inibitória ${ }^{[1,16]}$.

A desfosforilação do fitato é um pré-requisito para melhorar o valor nutricional, porque a remoção de grupos fosfato do anel inositol diminui a força de ligação mineral-fitato. Isso resulta em maior biodisponibilidade de minerais dietéticos essenciais. As fitases têm uma aplicação importante na nutrição humana tanto para a degradação do fitato durante o processamento dos alimentos quanto no trato gastrintestinal[ [] .

$\mathrm{Na}$ quinoa, o ácido fítico não está presente apenas nas camadas externas, como no caso do trigo e do centeio, mas também está distribuído uniformemente no endosperma ${ }^{[3,7,20]}$.

O teor de fitato é mais elevado no farelo do que na farinha ou na casca e representa de $38-41 \%$ do total de fitato das sementes inteiras ${ }^{[3]}$.

$\mathrm{Na}$ culinária caseira, para reduzir o teor de ácido fítico dos alimentos, os feijões e cereais integrais devem ser deixados de remolho em água (à temperatura ambiente) durante 8 a 12 horas antes do cozimento, e cozer sem a água de remolho ${ }^{[11]}$. Geralmente, cereais e leguminosas são encharcados em água durante a noite. O fitato é solúvel em água, 
então uma quantidade considerável de fitato é removida para a águal[?.

Khattak et al.[7] investigaram a influência do tempo de germinação e do tipo de iluminação em ácido fítico e polifenóis de grão-de-bico, sendo que com a iluminação utilizando a luz azul, observou-se uma diminuição significativa $(p<0,01)$ no teor de ácido fítico, enquanto que todas as outras iluminações não apresentaram esse efeito. O impacto da interação do tempo de germinação também foi altamente significativo.

Durante a germinação de cereais e leguminosas, o fitato é degradado pela fitase endógena. As sementes de plantas utilizam fitato como fonte de fosfato inorgânico durante a germinação e, portanto, tendem a aumentar a palatabilidade e o valor nutricional[?].

O processo de fermentação natural do pão com o uso de fermento biológico, e não químico, reduz o nível de ácido fítico do alimento ${ }^{[1]}$. $\mathrm{O}$ teor de fitato em massas de pão fresco foi reduzido pela adição de fitase, com os benefícios nutricionais subsequentes que implicam na redução do teor de antinutrientes dos pães contendo fibras ${ }^{[30]}$.

Quanto à fibra, somente quando a fibra está associada com ácido fítico há a redução na absorção de ferro e zinco, conforme Dietary Reference Intakes da IOM de 2006[31].

O farelo integral de arroz é rico em vitaminas, aminoácidos e ácidos graxos insaturados, no entanto, este farelo contém FANs, tais como o ácido fítico, inibidores de protease e ácido oxálico, o que limita a utilização na alimentação[ ${ }^{19]}$.

A hidrólise do ácido fítico proveniente da dieta ocorre na mucosa do intestino, sendo um processo totalmente dependente das enzimas produzidas pela microbiota ${ }^{[30]}$.

Quadro 3. Teor de fitato por massa de matéria seca em alimentos

\begin{tabular}{|c|c|}
\hline Alimentos & Fitato (mg/g) \\
\hline Pão francês & $0,2-0,4$ \\
\hline Pão de farinha mista (70\% de trigo, $30 \%$ de centeio) & $0,4-1,1$ \\
\hline Pão de farinha mista ( $70 \%$ de centeio, $30 \%$ de trigo) & $0-0,4$ \\
\hline Pão de centeio & $1,9-4,3$ \\
\hline Pão de trigo integral & $3,2-7,3$ \\
\hline Pão de trigo sem fermento & $3,2-10,6$ \\
\hline Pão de milho & $4,3-8,2$ \\
\hline Pão de milho sem fermento & $12,2-19,3$ \\
\hline Milho & $9,8-21,3$ \\
\hline Flocos de aveia & $8,4-12,1$ \\
\hline Arroz (polido, cozido) & $1,2-3,7$ \\
\hline Arroz (não polido, cozido) & $12,7-21,6$ \\
\hline Sorgo & $5,9-11,8$ \\
\hline Grão-de-bico (cozido) & $2,9-11,7$ \\
\hline Feijão caupi (cozido) & $3,9-13,2$ \\
\hline Feijão (cozido) & $8,3-13,4$ \\
\hline Feijão preto (cozido) & $8,5-17,3$ \\
\hline Feijão branco (cozido) & $9,6-13,9$ \\
\hline Feijão-de-lima (cozido) & $4,1-12,7$ \\
\hline Soja & $9,2-16,7$ \\
\hline Tofu & $8,9-17,8$ \\
\hline Lentilhas (cozidas) & $2,1-10,1$ \\
\hline Ervilhas (cozidas) & $1,8-11,5$ \\
\hline Amendoins & $9,2-19,7$ \\
\hline Sementes de gergelim (torradas) & $39,3-57,2$ \\
\hline Trigo sarraceno ou mourisco & $9,2-16,2$ \\
\hline Grão de amaranto & $10,6-15,1$ \\
\hline
\end{tabular}




\section{Ácido Oxálico $\left(\mathrm{C}_{2} \mathrm{H}_{2} \mathrm{O}_{4}\right)$}

O ácido oxálico ou oxalato é uma substância tóxica e representa risco importante para a saúde, e é abundante e frequentemente encontrado em diferentes tecidos vegetais, a exemplo do espinafre, ruibarbo, carambola, acelga, folha de beterraba, nozes, cacau, feijão, batata doce e tomate. Não pode ser metabolizado pelos humanos, sendo excretado na

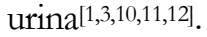

A dose letal do ácido oxálico é de $1.500 \mathrm{mg}$, no entanto, seu teor na maioria das plantas comestíveis é muito baixo para apresentar um sério risco. Porém, temos como exemplo, o ruibarbo (alimento que causou a morte durante a Primeira Guerra Mundial, de pessoas que se alimentaram de suas folhas) e o cacau que contém $500 \mathrm{mg}$ desse ácido em cada $100 \mathrm{~g}^{[26]}$.

A alta ingestão de oxalato na dieta influencia na absorção de minerais e desempenha papel-chave na hiperoxalúria, fator de risco para a formação de cálculos de oxalato de cálcio nos rins, devido à capacidade do oxalato de formar complexos insolúveis[3].

Segundo Scardelato et al.[32], a urina em condições normais é supersaturada de oxalato de cálcio, e cerca de $75 \%$ de todos os cálculos renais são compostos, principalmente, de oxalato de cálcio[1,3,25,26], e a hiperoxalúria é um dos principais fatores de risco para essa doença, porque o oxalato urinário origina de uma combinação da absorção de oxalato da dieta com os sintetizados endogenamente[1,3,25].

Numa mesma planta, diferentes partes podem ter diferentes níveis de oxalato por peso de tecido, como também há diferenças genéticas entre cultivares, de solo e condições de cultivo[23]. Em brotos de bambu (Phyllostachys pubescens), o principal ácido orgânico foi o oxálico, variando de $462 \mathrm{mg}$ (superior) a $157 \mathrm{mg}$ (base) por $100 \mathrm{~g}$ de peso fresco ${ }^{[2]} \mathrm{e}$, portanto, os brotos de bambu têm três vezes a concentração de oxalato em partes mais jovens contra as partes mais antigas. Em grãos integrais, o oxalato é concentrado na fração de farelo, de modo que no processamento de trigo para farinha refinada, cerca de um terço do oxalato é removido[23].

Benevides et al. ${ }^{[33]}$ observaram que, após o tratamento térmico (branqueamento a $100^{\circ} \mathrm{C} / 3 \mathrm{~min}$ ), houve uma redução no teor de oxalato de $8,4 \%$ para o jiló, $17,4 \%$ para o maxixe, $22,3 \%$ para o feijão verde e $22,91 \%$ para o feijão guandu, quando comparados com as amostras in natura; e na conserva em salmoura ácida do feijão verde, foi verificada a redução de $95 \%$ no teor de oxalato, em 90 dias de armazenamento.

O ácido oxálico tem sido responsável por significativo número de efeitos prejudiciais ao homem, como a diminuição da biodisponibilidade de minerais, a irritação gastrintestinal, a contração muscular ou tetania acompanhada de outros sintomas nervosos, a diminuição na capacidade de coagular o sangue, possíveis lesões nos órgãos excretores, etc., devido a deposição de substância celular com grande concentração de oxalato de cálcio cristalino ${ }^{[3,28]}$.

Antes havia pouco interesse nos valores de oxalato alimentar, porque o paradigma dominante era que o oxalato dietético contribuía com apenas $10 \%$ da excreção diária de oxalato. Isso mudou em 2001, quando Holmes et al.[34] mostraram que $24 \%$ a $53 \%$ de oxalato urinário é originário de oxalato dietético em ingestões de 10 a 250mg por dia. Seus resultados indicaram claramente que o oxalato dietético contribui muito mais para o oxalato urinário do que $\mathrm{o}$ reconhecido anteriormente. Holmes e Assinos ${ }^{[35]}$ revisaram a evidência de que a absorção e excreção de oxalato dietético pode ser um fator importante na formação de cálculos renais de oxalato de cálcio.

Os dados obtidos por Chai e Liebman ${ }^{[25]}$ indicaram que as oleaginosas possuem altos níveis de oxalato total, variando de 42 a $469 \mathrm{mg} / 100 \mathrm{~g}$ (equivalendo a cerca de 12 a $131 \mathrm{mg} /$ porção de $28 \mathrm{~g}$ ). Para pacientes com formação de cálculos renais, aconselha-se a restrição alimentar de oxalato, evitando os alimentos com teores mais altos como: espinafre, ruibarbo, beterraba (raiz tuberosa e folha), cacau, oleaginosas, chá preto (não verde ou à base de plantas), feijão, amendoim, soja, concentrados de farelo e cereais ${ }^{[23]}$. Os valores de oxalato relatados por Hönow e Hesse ${ }^{24]}$ para amêndoas [(383mg/100g), avelãs $(167 \mathrm{mg} / 100 \mathrm{~g})$ e pistache $(57 \mathrm{mg} / 100 \mathrm{~g})]$ foram semelhantes aos valores relatados na literatura[25].

As espécies pertencentes às famílias Polygonaceae (trigo-mourisco, ruibarbo e azedinha), Amaranthaceae (amaranto) e Chenopodiaceae (beterraba, espinafre, acelga e quinoa) estão incluídas na maioria dos vegetais que apresentam excessivas concentrações 
de oxalato. $\mathrm{O}$ oxalato se acumula, nessas famílias de plantas, em todos os tecidos vegetais, ou seja, nas folhas, caules, raízes, hipocótilo e sementes, sendo que o maior teor de oxalato foi encontrado nas folhas e caules ${ }^{[3]}$.

A restrição da ingestão de oxalato na dieta tem sido sugerida como um tratamento para prevenir a nefrolitíase recorrente em alguns pacientes. $O$ oxalato está presente em tecidos vegetais como uma combinação de fontes solúveis (oxalato de sódio e de potássio) e insolúveis (oxalato de cálcio e de magnésio), sendo os oxalatos solúveis mais biodisponíveis. A elevada quantidade de oxalato na urina aumenta o risco da formação de cálculos de oxalato de cálcio nos rins, pois o oxalato de cálcio é pouco solúvel na urina $a^{[1,2,3]}$, podendo também causar irritações na mucosa intestinal[1,3,26].

Quando os oxalatos dos alimentos são extraídos somente com água, o oxalato liberado é chamado oxalato solúvel. Os vegetais submetidos à fervura podem ser uma opção para reduzir o oxalato solúvel, se a água utilizada no cozimento não for consumida[23].

O oxalato é absorvido no estômago e no intestino[23,36]. Hatch e Freel[36] relataram que um estudo comparou a excreção urinária de oxalato após uma carga de oxalato (espinafre) em adultos saudáveis em comparação com pacientes com gastrectomia total. A excreção urinária de oxalato nos indivíduos saudáveis atingiu o pico em 40 minutos e novamente 3 horas após a carga. No entanto, nos pacientes com gastrectomia, o primeiro pico estava ausente, indicando uma contribuição da mucosa gástrica para a absorção de oxalato ao longo do trato digestório.

Oitenta a 90\% de uma carga oral de oxalato é excretada dentro de 8 a 11 horas, com a excreção de 95\% a 100\% em 24 horas. Isso é influenciado por três fatores principais: a quantidade e forma de oxalato nos alimentos consumidos, a quantidade de cálcio e magnésio nos alimentos e/ou na refeição que contém oxalato e a presença ou ausência de bactérias que degradam oxalato no intestino ${ }^{[23]}$.

O magnésio pode se ligar ao oxalato intraluminal e urinário e forma um sal mais solúvel do que o oxalato de cálcio, mas semelhante ao cálcio que é considerado insolúvel[36].

O consumo simultâneo de cálcio e/ou magnésio com oxalato reduz a absorção de oxalato, porque os sais insolúveis são formados no trato grastrintestinal. Liebman e Costa ${ }^{[37]}$ mostraram que o consumo de 300mg de cálcio ou magnésio com uma carga de 198mg de oxalato reduziu a absorção em cerca de 50\%. Zimmermann et al. ${ }^{[38]}$ relataram que $240 \mathrm{mg}$ de magnésio consumido com $2,4 \mathrm{mg}$ de oxalato reduziu a absorção de oxalato de $8,6 \%$ para $5,2 \%$ em voluntários saudáveis[23].

Vários microrganismos intestinais degradam o oxalato, incluindo Eubacterium lentum, Enterococcus faecalis, Lactobacillus spp, Streptococcus thermophilus, Bifidobacterium infantis e Oxalobacter formigenes[30]. O mais estudado é o Oxalobacter formigenes. A ausência ou baixos níveis de Oxalobacter formigenes foi relatado como associado a maiores níveis de excreção urinária de oxalato[23,36]. Vários outros estudos também mostraram que os pacientes formadores de pedra que são Oxalobacter-negativos têm excreção de oxalato urinário significativamente maior em comparação com pacientes com Oxalobacterpositivos ${ }^{36]}$.

Estudos mostraram que a absorção intestinal de oxalato é aumentada em formadores de pedra, bem como em pacientes com disfunção ileal e/ou esteatorréia ${ }^{[36]}$.

A ingestão total de cálcio deve ser dividida entre o maior número de ocasiões de comer possível. O cálcio irá se ligar ao oxalato no trato digestório, impedindo que ele seja absorvido. Os pacientes devem incluir cerca de $150 \mathrm{mg}$ de cálcio em cada refeição[23]. 
Quadro 4. Teor de oxalato publicados (mg/100g) em alimentos

\begin{tabular}{|l|c|c|}
\hline \multicolumn{1}{|c|}{ Alimento (100 g) } & Descrição & Valores publicados (mg) \\
\hline Espinafre & Cru & $400-900$ \\
\hline Ruibarbo & Cru ou cozido & $260-1.235$ \\
\hline Carambola & Cru & $121-916$ \\
\hline Beterraba & Folhas & $76-675$ \\
\hline Beterraba & Raiz & $170-623$ \\
\hline Cacau & Em pó & 457 \\
\hline Trigo & Farelo & 462 \\
\hline Broto de bambu* & Ponta do broto & 157 \\
\hline Broto de bambu* & Base do broto & \\
\hline
\end{tabular}

Fonte: Massey[23]; *Kozukue et al.[22].

Quadro 5.Teor de oxalato (mg/100g) em oleaginosas, avaliadas pelos métodos de eletroforese enzimática e capilar (CE)

\begin{tabular}{|l|c|c|c|}
\hline \multicolumn{1}{|c|}{ Alimento (100g) } & Descrição & $\begin{array}{c}\text { Teor de oxalato (mg) } \\
\text { 2 métodos }\end{array}$ & Média (mg) \\
\hline Amêndoa & Assada & $491 \mathrm{e} 447$ & 469 \\
\hline Castanha de Caju & Torrado & 263 e 260 & 262 \\
\hline Avelã & Crua & 221 e 223 & 222 \\
\hline Pinoli & Crua & 199 e 196 & 198 \\
\hline Amendoim & Assado & 131 e 148 & 74 \\
\hline Nozes & Cruas & 77 e 70 & 64 \\
\hline Noz Pecan & Crua & 66 e 62 & 49 \\
\hline Pistache & Assado & 51 e 46 & 42 \\
\hline Noz Macadâmia & Crua & 43 e 40 & \\
\hline
\end{tabular}

Quadro 6. Teor de oxalato $(\mathrm{mg} / 100 \mathrm{~g})$ de vários tipos de leguminosas cozidas até chegarem a uma consistência suave, analisadas pelos métodos de eletroforese enzimática e capilar (CE)

\begin{tabular}{|l|c|c|c|}
\hline \multicolumn{1}{|c|}{ Alimento (100g) } & Descrição & $\begin{array}{c}\text { Teor de oxalato (mg) } \\
\text { 2 métodos }\end{array}$ & Média (mg) \\
\hline Feijão anasazi & Grãos & 85 e 75 & 80 \\
\hline Feijão branco & Grãos pequenos & 77 e 78 & 78 \\
\hline Feijão rosa & Grãos & 75 e 75 & 75 \\
\hline Feijão preto & Grãos & 73 e 71 & 52 \\
\hline Soja & Grãos & 57 e 55 & 35 \\
\hline Feijão vermelho & Grãos pequenos & 36 e 33 & 16 \\
\hline Feijão vermelho & Grãos & 19 e 13 & 25 \\
\hline Feijão Azuki & Grãos & 26 e 23 & \\
\hline
\end{tabular}

Segundo Chai e Liebman[25], as farinhas analisadas continham níveis relativamente altos de oxalato total, variando de 37 a $269 \mathrm{mg} / 100 \mathrm{~g}$. Estes resultados podem ser úteis para pacientes com cálculos renais, uma vez que existem poucos dados relatados sobre os níveis de oxalato em vários tipos de farinhas. 
Quadro 7. Teor de oxalato em vários tipos de farinhas, avaliadas pelos métodos de eletroforese enzimática e capilar (CE)

\begin{tabular}{|l|c|c|}
\hline \multicolumn{1}{|c|}{ Alimento (100g) } & $\begin{array}{c}\text { Teor de oxalato }(\mathbf{m g}) \\
\text { 2 métodos }\end{array}$ & Média (mg) \\
\hline Trigo sarraceno & 271 e 267 & 269 \\
\hline Soja & 187 e 179 & 183 \\
\hline Trigo integral & 68 e 66 & 67 \\
\hline Trigo refinado & 41 e 38 & 40 \\
\hline Cevada & 59 e 53 & 56 \\
\hline Milho & 55 e 52 & 54 \\
\hline Centeio escuro & 52 e 49 & 51 \\
\hline Semolina & 48 e 48 & 48 \\
\hline Arroz integral & 38 e 35 & 37 \\
\hline
\end{tabular}

Fonte: Chai e Liebman ${ }^{[25]}$

\section{DISCUSSÃO}

O quadro abaixo sumariza os principais achados sobre os Fatores Antinutricionais, os métodos de redução desses fatores e as conclusões dos autores.

Quadro 8. Artigos pesquisados neste trabalho, os fatores antinutricionais abordados, métodos de redução e suas conclusões

\begin{tabular}{|c|c|c|c|c|c|}
\hline Autor e Ano & Título & Objetivo & $\begin{array}{c}\text { Fatores anti- } \\
\text { nutricionais } \\
\text { abordados }\end{array}$ & $\begin{array}{l}\text { Métodos de } \\
\text { redução dos } \\
\text { fatores }\end{array}$ & Conclusão \\
\hline $\begin{array}{l}\text { Santos } \\
2006\end{array}$ & $\begin{array}{lr}\text { Efeito r } & \text { do } \\
\text { cozimento } & \text { sobre } \\
\text { alguns fatores } \\
\text { antinutricionais em } \\
\text { folhas de brócolis, } \\
\text { de couve-flor e de } \\
\text { couve. }\end{array}$ & $\begin{array}{l}\text { Determinar os teores de } \\
\text { polifenóis, nitrato e ácido } \\
\text { oxálico em folhas de brócolis, } \\
\text { couve-flor e couve } \\
\text { submetidas à cocção por seis } \\
\text { diferentes tempos }(0,2,4,6 \text {, } \\
8 \text { e } 10 \text { minutos). }\end{array}$ & $\begin{array}{l}\text { Ácido oxálico, } \\
\text { nitrato e nitrito, } \\
\text { taninos. }\end{array}$ & $\begin{array}{l}\text { Cortes e cocção } \\
\text { em água fervente. }\end{array}$ & $\begin{array}{l}\text { Todas as espécies apresentaram redução nos teores } \\
\text { de fatores antinutricionais com o aumento do } \\
\text { tempo de cozimento. Portanto para utilização } \\
\text { dessas hortaliças, recomenda-se o cozimento } \\
\text { prévio para diminuição dos teores de substâncias } \\
\text { antinutricionais. Os teores presentes de ácido } \\
\text { oxálico não são suficientes para influenciar a } \\
\text { disponibilidade do cálcio no organismo. }\end{array}$ \\
\hline $\begin{array}{c}\text { Maradini } \\
\text { Filho }^{[3]} 2014\end{array}$ & $\begin{array}{l}\text { Caracterização } \\
\text { físico-química, } \\
\text { nutricional e fatores } \\
\text { antinutricionais de } \\
\text { quinoa da variedade } \\
\text { brasileira BRS } \\
\text { PIABIRU. }\end{array}$ & $\begin{array}{l}\text { Ampliar oconhecimento } \\
\text { sobre esse "pseudocereal", } \\
\text { caracterizar suas propriedades } \\
\text { físico-químicas e avaliar a } \\
\text { qualidade nutricional e os } \\
\text { fatores antinutricionais } \\
\text { de quinoa da variedade BRS } \\
\text { Piabiru, que foi desenvolvida } \\
\text { e adaptada às condições do } \\
\text { cerrado arasileiro, } \\
\text { comparando-a com a } \\
\text { variedade de quinoa Real } \\
\text { importada do Peru. }\end{array}$ & $\begin{array}{l}\text { Saponina, ácido } \\
\text { fítico, tanino, } \\
\text { nitrato e nitrito, } \\
\text { ácido oxálico e } \\
\text { inibidores de } \\
\text { protease (trip- } \\
\text { sina). }\end{array}$ & $\begin{array}{l}\text { Remolho, cozi- } \\
\text { mento, fervura em } \\
\text { água, lavagem em } \\
\text { água corrente. }\end{array}$ & $\begin{array}{l}\text { Os grãos de quinoa da variedade BRS Piabiru, } \\
\text { considerada "doce", apresentaram baixa } \\
\text { concentração de ácido fítico, taninos e nitratos, não } \\
\text { sendo detectada a presença de inibidores de } \\
\text { tripsina. Também apresentou saponinas em seus } \\
\text { grãos, diferentemente da variedade Real, } \\
\text { necessitando de sua remoção para lhes conferir } \\
\text { melhor gosto e melhor aceitação pelo consumidor. } \\
\text { Os baixos teores desses compostos indicam que a } \\
\text { farinha integral de quinoa da variedade brasileira } \\
\text { pode ser consumida sem risco para a saúde quanto } \\
\text { a esses fatores antinutricionais. }\end{array}$ \\
\hline $\begin{array}{c}\text { Fuentes }^{[5]} \\
2013\end{array}$ & $\begin{array}{l}\text { Cambios Bioquí- } \\
\text { micos en semillas de } \\
\text { Lupinus montanus y } \\
\text { Lupinus exaltatus } \\
\text { associados a trata- } \\
\text { mentos físicos, } \\
\text { químicos } \\
\text { germinativos. }\end{array}$ & $\begin{array}{l}\text { Avaliar o efeito de } \\
\text { tratamentos hidrotérmicos e } \\
\text { remolhos sobre a composição } \\
\text { química e a concentração de } \\
\text { alcaloides, fenóis totais, } \\
\text { taninos totais e taninos } \\
\text { condensados nas sementes de } \\
\text { L. montanus e L. exaltatus } \\
\text { (tremoços). Determinar a } \\
\text { concentração dos fatores } \\
\text { nutricionais e antinutricionais } \\
\text { nas sementes antes e depois } \\
\text { de } 3 \text { e } 6 \text { dias de um } \\
\text { tratamento germinativo. }\end{array}$ & $\begin{array}{l}\text { Saponinas, ácido } \\
\text { cianídrico, ácido } \\
\text { fítico, oligos- } \\
\text { sacarídeos, tani- } \\
\text { nos, inibidores } \\
\text { de protease. }\end{array}$ & $\begin{array}{l}\text { Remolho, cocção, } \\
\text { germinação, fer- } \\
\text { mentação, trata- } \\
\text { mento hidrotérmi- } \\
\text { co, torrefação, } \\
\text { fritura, extrusão, } \\
\text { remoção da casca e } \\
\text { melhoramento } \\
\text { genético. }\end{array}$ & $\begin{array}{l}\text { Os tratamentos físicos, químicos e biológicos } \\
\text { aplicados, mostraram efeito significativo sobre o } \\
\text { conteúdo nutricional e antinutricional das sementes } \\
\text { de L.montanus e L. exaltatus. O tratamento } \\
\text { hidrotérmico por } 6 \text { horas foi mais eficiente na } \\
\text { eliminação de FANs, mas não o suficiente para o } \\
\text { consumo humano. O tratamento germinativo por } \\
6 \text { dias, reduziu } 33,5 \text { e } 35,4 \% \text { no conteúdo de } \\
\text { alcaloides totais, sem redução dos fatores } \\
\text { nutricionais. }\end{array}$ \\
\hline
\end{tabular}


Quadro 8. Artigos pesquisados neste trabalho, os fatores antinutricionais abordados, métodos de redução e suas conclusões (continuação)

\begin{tabular}{|c|c|c|c|c|c|}
\hline Autor e Ano & Título & Objetivo & $\begin{array}{l}\text { Fatores anti- } \\
\text { nutricionais } \\
\text { abordados }\end{array}$ & $\begin{array}{l}\text { Métodos de } \\
\text { redução dos } \\
\text { fatores }\end{array}$ & Conclusão \\
\hline $\begin{array}{l}\text { Khattak et } \\
\text { al. }{ }^{77] 2007}\end{array}$ & $\begin{array}{l}\text { Influence of } \\
\text { germination } \\
\text { techniques on } \\
\text { phytic acid and } \\
\text { polyphenols content } \\
\text { of chickpea (Cicer } \\
\text { arietinum L.) sprouts. }\end{array}$ & $\begin{array}{l}\text { Investigar o impacto do } \\
\text { tempo de germinação e do } \\
\text { tipo de iluminação sobre o } \\
\text { conteúdo fenólico total e } \\
\text { ácido fítico em brotos de } \\
\text { grão de bico. }\end{array}$ & $\begin{array}{l}\text { Ácido fítico, } \\
\text { oligossacarídeos. }\end{array}$ & $\begin{array}{l}\text { Remolho, germina- } \\
\text { ção e iluminação. }\end{array}$ & $\begin{array}{l}\text { O tempo de germinação até } 48 \text { horas com a } \\
\text { iluminação da luz azul, observou-se uma } \\
\text { diminuição significativa no teor de ácido fítico, } \\
\text { enquanto que todas as outras iluminações não } \\
\text { tiveram o mesmo efeito. }\end{array}$ \\
\hline $\begin{array}{l}\text { Chisté et al. }{ }^{[13]} \\
2010\end{array}$ & $\begin{array}{l}\text { Quantificação de } \\
\text { cianeto total nas } \\
\text { etapas de processa- } \\
\text { mento das farinhas } \\
\text { de mandioca dos } \\
\text { grupos seca e } \\
\text { d'água. }\end{array}$ & $\begin{array}{l}\text { Quantificar a concentração } \\
\text { de cianeto total durante as } \\
\text { etapas de produção da farinha } \\
\text { de mandioca dos grupos seca } \\
\text { e d'água. }\end{array}$ & $\begin{array}{l}\text { Ácido } \\
\text { cianídrico. }\end{array}$ & $\begin{array}{l}\text { Trituração, prensa- } \\
\text { gem (remoção do } \\
\text { líquido), torrefação } \\
\text { da massa prensada, } \\
\text { exposição à tempe- } \\
\text { ratura elevada, } \\
\text { fermentação. }\end{array}$ & $\begin{array}{l}\text { O processamento da farinha de mandioca do } \\
\text { grupo seca e d'água trata-se de um processo efetivo } \\
\text { na destoxificação do cianeto na mandioca, uma vez } \\
\text { que a concentração de HCN durante as etapas } \\
\text { diminuiu drasticamente }(\sim 97 \%) \text { em ambos os } \\
\text { processos, garantindo a qualidade alimentar do } \\
\text { produto final, sem risco a saúde do consumidor. }\end{array}$ \\
\hline $\begin{array}{l}\text { Helbig et al.[16] } \\
2008\end{array}$ & $\begin{array}{l}\text { Análise dos teores } \\
\text { de ácidos cianídrico } \\
\text { e fítico em } \\
\text { suplemento alimen- } \\
\text { tar: multimistura. }\end{array}$ & $\begin{array}{l}\text { Quantificar o teor de ácido } \\
\text { cianídrico em folhas de } \\
\text { mandioca, que receberam } \\
\text { tratamento prévio antes da } \\
\text { secagem, e a concentração de } \\
\text { ácido fítico na multimistura } \\
\text { submetida à cocção úmida. }\end{array}$ & $\begin{array}{l}\text { Ácido fítico, } \\
\text { ácido cianídrico, } \\
\text { ácido oxálico. }\end{array}$ & $\begin{array}{l}\text { Maceração, seca- } \\
\text { gem das folhas, } \\
\text { moagem, processa- } \\
\text { mento térmico } \\
\text { (cocção, fervura, } \\
\text { torrefação), fer- } \\
\text { mentação } \\
\text { germinação. }\end{array}$ & $\begin{array}{l}\text { Verificou-se que a mudança na forma de secagem } \\
\text { das folhas de mandioca foi eficiente para a redução } \\
\text { de glicosídeos cianogênicos, e que o processo de } \\
\text { torrefação dos ingredientes foi suficiente para } \\
\text { produzir a redução de ácido fítico da multimistura } \\
\text { aos níveis preconizados pela legislação, não sendo } \\
\text { observadas diferenças estatisticamente significantes } \\
\text { quando comparadas às amostras que também } \\
\text { foram tratadas com calor úmido. }\end{array}$ \\
\hline $\begin{array}{l}\text { Chai e } \\
\text { Liebman }^{[25]} \\
2005\end{array}$ & $\begin{array}{l}\text { Oxalate content of } \\
\text { legumes, nuts, and } \\
\text { grain-based flours. }\end{array}$ & $\begin{array}{l}\text { Analisar os níveis urinários de } \\
\text { oxalato, o oxalato de } \\
\text { leguminosas, nozes e } \\
\text { diferentes tipos de farinhas à } \\
\text { base de grãos. }\end{array}$ & Oxalato. & $\begin{array}{l}\text { Remolho e fervura } \\
\text { em água destilada/ } \\
\text { deionizada até } \\
\text { chegarem a uma } \\
\text { consistência suave. }\end{array}$ & $\begin{array}{l}\text { O oxalato total avaliado através dos métodos de } \\
\text { eletroforese enzimática e capilar (CE) variou muito } \\
\text { entre as leguminosas testadas, variando de } 4 \text { a } \\
80 \mathrm{mg} / 100 \mathrm{~g} \text { de peso cozido; nas nozes de } 42 \mathrm{a} \\
469 \mathrm{mg} / 100 \mathrm{~g} \text {, e nas farinhas de } 37 \mathrm{a} 269 \mathrm{mg} / 100 \mathrm{~g} \text {. } \\
\text { Os dados gerais sugerem que a maioria das } \\
\text { leguminosas, nozes e farinhas são fontes ricas em } \\
\text { oxalato. }\end{array}$ \\
\hline $\begin{array}{l}\text { Santos [26] } \\
\quad 2015\end{array}$ & $\begin{array}{l}\text { Caracterização e } \\
\text { utilização de sub- } \\
\text { produtos do mamão } \\
\text { (Carica papaya L.). }\end{array}$ & $\begin{array}{l}\text { Caracterizar quimicamente a } \\
\text { farinha da casca e semente de } \\
\text { frutos obtidos de dois } \\
\text { cultivares de mamão (Havaí e } \\
\text { Calimosa), em relação aos } \\
\text { nutrientes, aos antinutrientes } \\
\text { e à capacidade antioxidante, e } \\
\text { elaborar pães de forma } \\
\text { integrais adicionados dessas } \\
\text { farinhas. }\end{array}$ & $\begin{array}{l}\text { Inibido-res de } \\
\text { proteases, ácido } \\
\text { fítico, ácido } \\
\text { oxálico, nitratos } \\
\text { e nitritos. }\end{array}$ & $\begin{array}{l}\text { Processamento } \\
\text { térmico e moagem. }\end{array}$ & $\begin{array}{l}\text { As inibições de tripsina e os teores de } \\
\text { antinutrientes encontrados neste estudo são baixos } \\
\text { e não inviabilizam o uso das farinhas de casca e } \\
\text { semente de mamão como fonte de nutrientes. }\end{array}$ \\
\hline $\begin{array}{c}\text { Lopes et al. }[28] \\
2009\end{array}$ & $\begin{array}{l}\text { Aproveita-mento, } \\
\text { composição nutri- } \\
\text { cional } \quad \mathrm{e} \\
\text { antinutricio-nal da } \\
\text { farinha de quinoa } \\
\text { (Chenopodium } \\
\text { Quinos). }\end{array}$ & $\begin{array}{l}\text { Elaborar uma farinha de } \\
\text { quinoa, caracterizar a sua } \\
\text { composição nutricional e } \\
\text { antinutricional, além de } \\
\text { aproveitá-la na formulação de } \\
\text { bolinhos fritos e avaliar sua } \\
\text { aceitabilidade. }\end{array}$ & $\begin{array}{l}\text { Ácido oxálico, } \\
\text { inibidores de } \\
\text { protease, ácido } \\
\text { fítico, nitrato. }\end{array}$ & Trituração. & $\begin{array}{l}\text { Os antinutrientes avaliados foram baixos, não } \\
\text { apresentando, portanto, riscos à nutrição e à saúde } \\
\text { humana. A farinha de quinoa constitui matéria- } \\
\text { prima para a elaboração de bolinhos fritos, sendo } \\
\text { bem aceitos pelos julgadores. }\end{array}$ \\
\hline $\begin{array}{l}\text { Almeida } e t \\
a l .{ }^{29]} 2014\end{array}$ & $\begin{array}{l}\text { Caracterização quí- } \\
\text { mica das hortaliças } \\
\text { não convencio-nais } \\
\text { conhecidas como } \\
\text { ora-pro-nobis. }\end{array}$ & $\begin{array}{l}\text { Realizar a caracterização } \\
\text { química das hortaliças não } \\
\text { convencionaisconhecidas } \\
\text { como ora-pro-nobis (Pereskia } \\
\text { aculeata e Pereskia grandifolia). }\end{array}$ & $\begin{array}{l}\text { Ácido oxálico, } \\
\text { nitrato, saponi- } \\
\text { nas,compostos } \\
\text { fenólicos e } \\
\text { inibidores de } \\
\text { proteases. }\end{array}$ & $\begin{array}{l}\text { Desidratação } \\
\text { trituração. }\end{array}$ & $\begin{array}{l}\text { Conclui-se que as folhas destas cactáceas são } \\
\text { importantes fontes de proteínas, fibras, minerais } \\
\text { (principalmente o cálcio e o ferro) e de compostos } \\
\text { bioativos. Mesmo sendo detectados antinutrientes } \\
\text { nas farinhas, seu consumo diário não será } \\
\text { suficiente para causar malefícios à saúde humana. }\end{array}$ \\
\hline $\begin{array}{l}\text { Benevides et } \\
\text { al. } .^{[33]} \\
2013\end{array}$ & $\begin{array}{l}\text { Efeito do proces- } \\
\text { samento sobre os } \\
\text { teores de oxalato e } \\
\text { tanino em maxixe } \\
\text { (Cucumis anguria L.), } \\
\text { jiló (Solanum gilo), } \\
\text { feijão verde (Vigna } \\
\text { unguiculata L.) e } \\
\text { feijão guandu } \\
\text { (Cajanus cajan L.). }\end{array}$ & $\begin{array}{l}\text { Avaliar o efeito } \\
\text { doprocessamento térmico e } \\
\text { do armazenamento em } \\
\text { salmoura ácida, em função do } \\
\text { tempo, nos teores de } \\
\text { substâncias antinutricionais } \\
\text { em hortaliças (maxixe e jiló) e } \\
\text { leguminosas (feijão verde e } \\
\text { feijão guandu) } \\
\text { comercializadas em Salvador- } \\
\text { BA. }\end{array}$ & $\begin{array}{l}\text { Oxalatos } \\
\text { taninos. }\end{array}$ & $\begin{array}{l}\text { Tratamentotérmi- } \\
\text { co (branquea- } \\
\text { mento), conserva } \\
\text { em salmoura ácida. }\end{array}$ & $\begin{array}{l}\text { O processamento térmico (branqueamento) e a } \\
\text { conserva em salmoura ácida durante o } \\
\text { armazenamento contribuiu efetivamente para } \\
\text { redução dos teores de taninos e oxalatos nas } \\
\text { amostras de maxixe, jiló, feijão caupi e feijão } \\
\text { guandu. Os valores de taninos e oxalatos } \\
\text { encontrados nesta pesquisa nas hortaliças e } \\
\text { leguminosas não oferecem risco para o } \\
\text { consumidor. }\end{array}$ \\
\hline
\end{tabular}


Quadro 8. Artigos pesquisados neste trabalho, os fatores antinutricionais abordados, métodos de redução e suas conclusões (continuação)

\begin{tabular}{|c|c|c|c|c|c|}
\hline Autor e Ano & Título & Objetivo & $\begin{array}{c}\text { Fatores anti- } \\
\text { nutricionais } \\
\text { abordados }\end{array}$ & $\begin{array}{l}\text { Métodos de } \\
\text { redução dos } \\
\text { fatores }\end{array}$ & Conclusão \\
\hline $\begin{array}{l}\text { Damiani et } \\
\text { al.[39] } 2013\end{array}$ & $\begin{array}{l}\text { Perfil de ácidos } \\
\text { graxos e fatores } \\
\text { antinutricionais de } \\
\text { amêndoas de pequi } \\
\text { crua e torrada. }\end{array}$ & $\begin{array}{l}\text { Verificar a composição } \\
\text { centesimal, o perfil de ácidos } \\
\text { graxos e os fatores } \\
\text { antinutricionais em amêndoas } \\
\text { de pequi crua e torrada (a } \\
270^{\circ} \mathrm{C} \text {, por } 15 \text { minutos), } \\
\text { oriundas do Estado de Goiás. }\end{array}$ & $\begin{array}{l}\text { Fitato, tanino e } \\
\text { inibidores de } \\
\text { tripsina. }\end{array}$ & $\begin{array}{l}\text { Torrefação e moa- } \\
\text { gem. }\end{array}$ & $\begin{array}{l}\text { Não foi verificada a presença de inibidores de } \\
\text { tripsina nas amêndoas de pequi crua e torrada. Os } \\
\text { teores de taninos }(1,21 \% \text { e } 1,17 \%) \text { e fitatos }(2,64 \% \\
\text { e } 1,86 \%) \text { reduziram-se significativamente, após a } \\
\text { torrefação, indicando certa instabilidade destes } \\
\text { componentes, em relação ao calor. }\end{array}$ \\
\hline $\begin{array}{c}\text { Moraes et al. } .^{[40]} \\
2010\end{array}$ & $\begin{array}{l}\text { Qualidade proteica } \\
\text { e eficiência } \\
\text { alimentar de } \\
\text { farinhas integrais de } \\
\text { linhaça obtidas de } \\
\text { sementes cruas e } \\
\text { submetidas a trata- } \\
\text { mento térmico. }\end{array}$ & $\begin{array}{l}\text { Avaliar a digestibilidade, a } \\
\text { qualidade proteica, a } \\
\text { eficiência alimentar, a } \\
\text { concentração de fibra } \\
\text { alimentar e de fitoquímicos } \\
\text { com ação antinutriente em } \\
\text { farinhas integrais de linhaça } \\
\text { marrom crua e submetida a } \\
\text { tratamento térmico. }\end{array}$ & $\begin{array}{l}\text { Ácido fítico, } \\
\text { tanino, ácido } \\
\text { oxálico, saponi- } \\
\text { na, glicosídios } \\
\text { cianogênicos, } \\
\text { oligossacarídeos, } \\
\text { inibidores de } \\
\text { protease. }\end{array}$ & $\begin{array}{l}\text { Tratamento térmi- } \\
\text { co e trituração. }\end{array}$ & $\begin{array}{l}\text { A farinha de linhaça crua e submetida a tratamento } \\
\text { térmico, apresentou redução nos teores de ácido } \\
\text { fítico (redução de } 10 \% \text { no teor de IP6 e de } 80 \% \text { do } \\
\text { IP5), mas não interferiu na qualidade proteica da } \\
\text { farinha de linhaça. }\end{array}$ \\
\hline
\end{tabular}

Conforme Fuentes [5], os tratamentos físicos, químicos e biológicos aplicados mostraram efeito significativo sobre o conteúdo nutricional e antinutricional (ácido cianídrico, ácido fítico) das sementes de Lupinus montanus e Lupinus exaltatus (tremoços).

Segundo Chisté et al.[13], o processamento da farinha de mandioca do grupo seca e d'água, é um processo efetivo na destoxificação do cianeto na mandioca, uma vez que a concentração de HCN durante as etapas diminuiu drasticamente (aproximadamente 97\%), garantindo a qualidade alimentar do produto final, sem risco a saúde do consumidor.

Helbig et al.[16] verificaram que a técnica de amassar e rasgar as folhas de mandioca antes de as colocar para secar foi eficiente para a redução de glicosídeos cianogênicos, e que o processo de torrefação dos ingredientes foi suficiente para a redução de ácido fítico na multimistura.

Conforme registrado por Chai e Liebman[25], o oxalato total avaliado através dos métodos de eletroforese enzimática e capilar (CE) variou muito, sendo entre as leguminosas testadas, variando de 4 a $80 \mathrm{mg} / 100 \mathrm{~g}$ de peso cozido; nas nozes de 42 a $469 \mathrm{mg} / 100 \mathrm{~g}$, e nas farinhas de 37 a $269 \mathrm{mg} / 100 \mathrm{~g}$, e concluíram que vários são fontes ricas em oxalato.

Conforme Maradini Filho[3], Santos ${ }^{[26]}$ e Lopes et al.[28], os antinutrientes (ácido oxálico, ácido fítico) avaliados na quinoa da variedade BRS Piabiru, nas farinhas de casca e semente de mamão e na farinha de quinoa respectivamente, foram baixos, portanto não apresentando riscos à nutrição e à saúde humana.

Observou-se, segundo Khattak et al.[7], que no tempo de germinação em grão de bico até 48 horas, com a iluminação da luz azul, houve uma diminuição significativa no teor de ácido fítico, enquanto que todas as outras iluminações não tiveram o mesmo efeito.

Segundo Damiani et al.[39] e Moraes et al.[40], o tratamento térmico reduziu os teores de ácido fítico em estudos com amêndoas de pequi $(2,64 \%$ para $1,86 \%$ ) e farinha de linhaça (redução de $10 \%$ no teor de IP6 e de $80 \%$ do IP5).

A PANC ora-pro-nobiscontém antinutrientes como o ácido oxálico na sua farinha obtida através da secagem e moagem das folhas, porém seu consumo diário não será suficiente para causar malefícios à saúde humana, segundo Almeida et al.[29].

O processamento térmico (branqueamento) e a conserva em salmoura ácida durante o armazenamento contribuiu efetivamente para redução dos teores de oxalato em maxixe, jiló, feijão caupi e feijão guandu, não oferecendo risco para o consumidor, conforme registrado por Benevides et al. [33]. 
Segundo Santos ${ }^{[2]}$, as folhas de brócolis, de couve-flor e de couve, quando submetidas à água destilada em ebulição e depois escorridas, os teores presentes de ácido oxálico não foram suficientes para influenciar na biodisponibilidade do cálcio no organismo.

\section{CONCLUSÃO}

Por meio desta revisão pode-se concluir que, dependendo da dose ingerida, o ácido cianídrico e o ácido oxálico, por serem substâncias tóxicas, podem chegar a ser letal, e que o ácido fítico pode reduzir a biodisponibilidade de minerais importantes para a nossa saúde.

Para reduzir o conteúdo de ácido cianídrico dos alimentos, deve-se fazer uso de processos de preparação como remolho, cocção, fatiagem, maceração, trituração, fermentação, secagem e torrefação, pois estima-se que o consumo de alimento contendo uma concentração entre 0,5 a $3,5 \mathrm{mg}$ de $\mathrm{HCN}$ por $\mathrm{kg}$ de peso corpóreo, possa levar o indivíduo à morte em poucos minutos.

No caso do ácido fítico é importante que ocorra a desfosforilação, pois assim o fitato perderá a sua capacidade de formar complexos insolúveis com minerais bi e trivalentes como cálcio, ferro, magnésio, zinco, cobre e potássio, e assim reduzindo a interferência na biodisponibilidade desses minerais. Para que ocorra a desfosforilação deve-se fazer uso no preparo de alimentos, de remolho (e após cozer sem a água de remolho), germinação, fermentação, processamento, maltagem, moagem e tratamento térmico. Em termos de produção industrial, pode-se indicar a adição de fitases exógenas estáveis ao calor e que atue em ampla faixa de $\mathrm{pH}$.

Quanto ao ácido oxálico, a dose letal é de $1.500 \mathrm{mg}$, e para os formadores de cálculo renal é extremamente importante conhecer quais alimentos contêm níveis elevados de oxalato e evitar o seu consumo, pois ao complexar com o cálcio ou magnésio formam cristais insolúveis. O oxalato que é liberado na água é chamado oxalato solúvel que se complexa com sódio e potássio, por isso ao submeter à fervura vegetais ricos em ácido oxálico, a água utilizada no cozimento deve ser desprezada. Também, o consumo simultâneo de cálcio e/ou magnésio com alimentos ricos em ácido oxálico reduz sua absorção, porque os cristais insolúveis são formados no sistema digestório.

\section{REFERÊNCIAS}

[1] Benevides CMJ, Souza MV, Souza RDB, Lopes MV. Fatores antinutricionais em alimentos: revisão. Segur. Aliment. Nutr. 2011:18(2):67-79.

[2] Santos MAT. Efeito do cozimento sobre alguns fatores antinutricionais em folhas de brócoli, couve-flor e couve. Ciênc. Agrotec.2006;30(2):294-301.

[3] Maradini Filho AM. Caracterização físico-química, nutricional e fatores antinutricionais de quinoa da variedade brasileira BRS PIABIRU [tese]. Viçosa: Universidade Federal de Viçosa; 2014.

[4] Fernandes AC. Tipos de feijões e técnicas de preparo utilizadas em unidades produtoras de refeições das regiões Sul e Sudeste do Brasil [dissertação]. Florianópolis: Universidade Federal de Santa Catarina; 2010.

[5] Fuentes BJ. Cambios Bioquímicos en semillas de Lupinus montanus y Lupinus exaltatus associados a tratamentos físicos, químicos y germinativos [dissertação]. Tabasco: Institución de Enseñanza e Investigación en Ciencias Agrícolas; 2013.

[6] Queiroz ER, Abreu CMP, Rocha DA, Simão AA, Bastos VAA, Botelho LNS, et al. Anti-nutritional compounds in fresh and dried lychee fractions (Litcbi cbinensis Sonn). Afr. J. Agric. Res. 2015;10(6):499-504.

[7] Khattak AB, Zeb A, Bibi N, Khalil SA, Khattak MS.Influence of germination techniques on phytic acid and polyphenols content of chickpea (Cicer arietinum L.) sprouts. Food Chemistry. 2007;104:1074-109.

[8] Rubio LA, Muzquiz M, Burbano C, Cuadrado C, Pedrosa MM. High apparent ileal digestibility of amino acids in raw and germinated faba bean (Vicia faba) - and chickpea (Cicer arietinum) based diets for rats.Journal of the Science of Food and Agriculture. 2002;82:1710-1717.

[9] Kumar V, Sinha AK, Makkar HPS, Becker K. Dietary roles of phytate and phytase in human nutrition: A review. Food Chemistry. 2010;120:945-959.

[10] Mahan LK, Scott-Stump S, Raymond JL. Krause: Alimentos, Nutrição e Dietoterapia. 13. ed. Rio de Janeiro: Elsevier Editora; 2012.

[11] Slywitch E. Guia alimentar de dietas vegetarianas para adultos [Internet]. São Paulo: Sociedade Vegetariana Brasileira, Departamento de Medicina e Nutrição; 2012 [acesso em 28 abr 2017]. Disponível em: https://www.svb.org.br/livros/guiaalimentar.pdf 
[12] Hackbarth L. Estado nutricional de vegetarianos e onívoros usuários de restaurantes universitários [dissertação]. Curitiba: Universidade Federal do Paraná; 2015.

[13] Chisté RC, Cohen KO, Mathias EA, Oliveira SS. Quantificação de cianeto total nas etapas de processamento das farinhas de mandioca dos grupos seca e d'água. Acta Amaz. 2010;40(1):221-226.

[14] Cardoso Junior NS, Viana AES, Matsumoto SN, Sediyama T, Amaral CLF, Pires AJV,et al. Efeito do nitrogênio sobre o teor de ácido cianídrico em plantas de mandioca. Acta Sci. Agron. 2005;27(4):603-610.

[15] Amorim SL, Medeiros EMT, Rietcorrea F. Intoxicações por plantas cianogênicas no Brasil. Ciência Animal. 2006;16(1):17-26.

[16] Helbig E, Buchweitz MRD, Gigante DP. Análise dos teores de ácidos cianídrico e fítico em suplemento alimentar: multimistura. Rev. Nutr. 2008;21(3): 323-328.

[17] Mazur CE. Efeitos do Feijão Branco (Phaseolus vulgaris L.) na perda de peso. Rev. Bras. Nutrição Esportiva. 2014;8(48):404-411.

[18]Greiner R, Konietzny U. Phytase for Food Application. Food Technol. Biotechnol. 2006;44(2):125-140.

[19] Piyaratne MKDK, Atapattu NSBM, Mendis APS, Amarasinghe AGC. Effects of balancing rice bran based diets for up to four amino acids on growth performance of broilers. Tropical Agricultural Research \& Extension. 2009;12(2):57-61.

[20]Vega-Gálvez A, Miranda M, Vergara J, Uribe E, Puente L, Martínez EA. Nutrition facts and functional potential of quinoa (Chenopodium quinoa willd.), an ancient Andean grain: a review. Journal of the Science of Food and Agriculture. 2010;90:2541-2547.

[21] Lozano MG. Amendoim (arachis hypogaea L.): composição centesimal, ácidos graxos, fatores antinutricionais e minerais em cultivares produzidas no Estado de São Paulo [dissertação]. Piracicaba: Universidade de São Paulo; 2016.

[22] Kozukue E, Kozukue N, Kurosaki T. Organic Acid, Sugar and Amino Acid Composition of Bamboo Shoots. Journal of Food Science. 1983;48(3):935-938.

[23] Massey LK. Food Oxalate: Factors Affecting Measurement, Biological Variation, and Bioavailability. Journal of the American Dietetic Association. 2007;107(7):1191-1194.

[24] Hönow R, Hesse A. Comparison of extraction methods for the determination of soluble and total oxalate in foods by HPLCenzyme-reactor. Food Chemistry. 2002;78(4):511-521.

[25] Chai W, Liebman M. Oxalate content of legumes, nuts and grain-based flours. Journal of Food Composition and Analysis. 2005;18(7):723-729.
[26] Santos CM. Caracterização e Utilização de Subprodutos do Mamão (Carica papaya L.) [tese]. Lavras: Universidade Federal de Lavras; 2015.

[27] Santos CD. Avaliação das melhores condições de secagem de grãos de soja visando à manutenção do teor de proteínas [dissertação]. Porto Alegre: Universidade Federal do Rio Grande do Sul; 2013

[28] Lopes CO, Dessimoni GV, Silva MC, Vieira G, Pinto NAVD. Aproveitamento, composição nutricional e antinutricional da farinha de quinoa (Chenopodium Quinos). Alim. Nutr. 2009;20(4):669675 .

[29] Almeida MEF, Junqueira AMB, Simão AA, Corrêa AD. Caracterização química das hortaliças não convencionais conhecidas como ora-pro-nobis. Biosci. J. 2014;30(1):431-439.

[30] Sato VS. Produção de fitase por Rhizopus microsporus var. microsporus. Purificação, Caracterização Bioquímica e Aplicação [tese]. Araraquara: Universidade Estadual Paulista "Julio de Mesquita Filho"; 2015.

[31] Institute of Medicine (IOM). Dietary Reference Intakes: The Essential Guide to Nutrient Requirements. Washington, D.C.: The National Academies Press; 2006.

[32] Scardelato JÁ, Legramandi VHP, Sacramento LVS. Ocorrência de cristais em plantas medicinais utilizadas no tratamento da nefrolitíase: paradoxo? Rev. Ciênc. Farm. Básica Apl. 2013;34(2):161-168.

[33] Benevides CMJ, Souza RDB, Souza MV, Lopes MV. Efeito do processamento sobre os teores de oxalato e tanino em maxixe (Cucumis anguria L.), jiló (Solanum gilo), feijão verde (Vigna unguiculata (L.) Walp) e feijão andu (Cajanus cajan (L.) Millsp. Alim. Nutr. Braz. J. Food Nutr. 2013;24(3):321-327.

[34] Holmes RP, Goodman HO, Assinos DG. Contribution of dietary oxalate to urinary oxalate excretion. Kidney Internacional. 2001;59(1):270-276.

[35] Holmes RP, Assinos DG. The impact of dietary oxalate on kidney stone formation. Urol Res. 2004;32:311-316.

[36] Hatch M, Freel RW. Intestinal transport of an obdurate anion: oxalate. Urological Research. 2005;33(1):1-16.

[37] Liebman M, Costa G. Effects of calcium and magnesium on urinary oxalate excretion after oxalate loads. The Journal of Urology. 2000;163(5):1565-1569.

[38] Zimmermann D, Voss S, Unruh GE, Hesse A.Importance of Magnesium in Absorption and Excretion of Oxalate. Urol Int. 2005;74:262-267.

[39] Damiani C, Almeida TL, Costa NV, Medeiros NX, Silva AGM, Silva FA, et al. Perfil de ácidos graxos e fatores 
antinutricionais de amêndoas de pequi crua e torrada. Pesq. Agropec. Trop. 2013;43(1):71-78.

[40] Moraes EA, Carraro, JCC, Dantas MIS, Costa NMB, Ribeiro SMR, Martino HSD. Qualidade proteica e eficiência alimentar de farinhas integrais de linhaça obtidas de sementes cruas e submetidas a tratamento térmico. Rev. Inst. Adolfo Lutz. 2010;69(4):531-536. 